\title{
Outdoor Psychomotor Activities: Bringing Children to Nature
}

\author{
Daniel Klein, Stefan Türk, Ralf Roth \\ Institute of Outdoor Sports and Environmental Science, German Sport University Cologne, Cologne, Germany \\ Email:d.klein@dshs-koeln.de
}

How to cite this paper: Klein, D., Türk, S., \& Roth, R. (2018). Outdoor Psychomotor Activities: Bringing Children to Nature. Advances in Physical Education, 8, 246-252. https://doi.org/10.4236/ape.2018.82022

Received: April 20, 2018

Accepted: May 26, 2018

Published: May 29, 2018

Copyright $\odot 2018$ by authors and Scientific Research Publishing Inc. This work is licensed under the Creative Commons Attribution International License (CC BY 4.0).

http://creativecommons.org/licenses/by/4.0/

\begin{abstract}
Due to the dominating passive consumption of audio-visual media, children today spend less time being active in nature. Sedentary behavior may lead to severe health problems like being overweight or obese, whereas positive effects of physical activity are well proven. Physical activity outdoors seems to result in additional positive effects. Therefore, it may be regarded as a public health issue to bring children back to nature and encourage them to be physically active in this setting. The following article discusses how the child-centered approach of psychomotricity can be transferred to natural surroundings. Central to this approach is the experience of self-efficacy. Outdoor environments offer numerous starting points to implement psychomotor sessions; practical options are exemplified below.
\end{abstract}

\section{Keywords}

Outdoor Education, Psychomotricity

\section{Introduction}

Children today in most industrialized countries are growing up in altered living conditions compared to previous times. Due to urbanization, motorization and rapid technological progress, children spend less time actively playing in natural surroundings and more time passively consuming audio-visual media, which may lead to an increasing alienation from nature (Kruger et al., 2010; San Jose \& Nelson, 2017). Moreover, sedentary behavior potentially results in poor motor performance and being overweight and may negatively impact the emotional, psycho-social and cognitive development of children (Marshall et al., 2004; Roth et al., 2010; Tomkinson et al., 2003; Zimmer, 2012).

The positive effects of physical activity in general are well documented and physical activity in outdoor natural environments may lead to additional posi- 
tive effects (Thompson Coon et al., 2011; Pesce et al., 2016). For example, children who are physically active outside have a lower risk for developing chronic illnesses (Strong et al., 2005) and physical activity in natural environments was found to be associated with a lower risk of poor mental health (Mitchell, 2013). Importantly, Wells and Lekies (2006) point out that the number of hours spent outdoors in childhood is the most important factor associated with people's long-term environmental attitudes and behaviors. Frequent experiences in nature during childhood predict higher levels of physical activity in natural environments in adulthood (Calogiuri, 2016). Therefore, it may be a public health issue to bring children back to nature as early and as often as possible.

\section{Principles of Psychomotricity}

The concept of psychomotricity implies a strong connection of mental and motor processes and development. It offers a holistic approach, in which the individual human being is in the center of consideration. A close relationship between action, emotion and cognition is taken as a basis.

Psychomotricity in general is suitable for children and adults of every age, even though most psychomotor activities are conducted for young children at preschool age. Main objects of psychomotricity, especially the child-centered approach of Zimmer (2012), are to foster children's perception, motor skills and self-concept. Children are expected to benefit from psychomotor activities in this respect.

Zimmer (2012) emphasizes the following basic principles of psychomotricity:

- To experience self-efficacy

- To attribute success or failure to the own person

- To deal with individual moral values and to orient the own behavior towards these

- To take on responsibility for own action

- To get to know alternatives to disruptive behavior and to integrate them into their behavior

In this regard, natural surroundings offer numerous opportunities. It has been shown that contact with nature has a beneficial effect on the physical and emotional health of children (Kruger et al., 2010). Nevertheless, psychomotor activities often are conducted in closed rooms. Therefore the question arises, how principles of psychomotricity may be transferred to outdoor activities to bring children back to nature.

According to the above-mentioned principles some exemplified suggestions may be:

- Children experience self-efficacy when they climb a tree or build a lodge

- Internal attribution may require an initiated reflection or feedback from the teacher

- Moral values are an important issue concerning environmentalism and appropriate behavior in nature

- Children may take on responsibility in social situations like building a bridge 
over a runnel

- In nature, it is important to follow rules like not disturbing animals in their habitat

All senses are stimulated in natural environments, so that a holistic promotion of motor, psycho-social and emotional aspects is possible, if the basic principles of psychomotricity are transferred to activities in nature. This may be regarded as a plus factor compared to general physical activity. Moreover, numerous experiences may occur as teachable moments, that do not necessarily require any tasks formulated by the teacher. These experiences may differ through the annual cycle of seasons.

\section{Options of Practical Implementation}

Stimulative nature of the surrounding generally leads to physical activities of children like running, climbing or hiding. When children walk barefoot on grounds like a meadow, forest floor or stones, they gain tactile experiences. When they balance on a downed log it is vestibular experience, when they observe the interplay of light and shade it is visual experience, when they listen to swooshing leaves it is auditory experience, when they smell moss it is olfactory experience and when they taste fruits it is gustatory experience they make, just to provide some examples.

Psychomotor classes often are structured in four phases (Köckenberger, 2010): 1) attunement, 2) exploration, 3) main phase and 4) relaxation. The following suggestions are exemplified and of course have to be adapted to target groups and external conditions or modified where appropriate.

\subsection{Attunement}

The first phase aims at psycho-physical attunement. Introductory stories, fixed rituals or warm-up games are paramount in this phase. Children's well-being should be checked by the teacher-a simple method is the thumbs up sign.

\subsection{Exploration}

The second phase is of high importance. Children are confronted with the conditions of natural surroundings, experience physical laws and learn in an investigative and experimental way (Zimmer, 2012). Perceptual systems are stimulated, creativity is fostered, emotional expression and social contacts are initiated (Köckenberger, 2010). Thus, experiences of self-efficacy are facilitated.

Psychomotor activities in nature do not necessarily require special material to be brought along. Natural materials that are found outdoors may be used instead. If children gain experiences on their own, they do create individual contexts like making up games or slipping into imaginative roles. Teachers can use this phase for diagnostic observations and take up children's ideas in the following phase. 


\subsection{Main Phase}

The teacher provides perceptual and motional experiences in the main phase. A brief reflection on the previous phase should be facilitated by the teacher. Children should get the opportunity to report the experiences they have made, followed by purposeful tasks formulated by the teacher. Many indoor games may be transformed in a way that they are appropriate to be played in outdoor settings. Moreover, there are no limits to the imagination of the teacher and participating children. Three exemplified options are (Klein \& Kurth, 2017; Grüger $\&$ Weyhe, 2007):

- "Awake trees": Children line up on a meadow and imagine being trees. One child is the sun that awakens the trees one by one by rubbing their bark. Every tree that woke up becomes another sun and helps the original one until all tress are awaked. This game fosters tactile perception.

- "Placing outlines": Children pick out a tree, a rock or something else that they like and copy its outline by placing branches or stones on the ground. This game fosters visual perception and figure-ground perception.

- "Thieving predators": Children are subdivided into mice and squirrels. The squirrels look for a quiet place to take a nap (children close their eyes), their collected fir cones located in front of them. The mice try to creep up intending to steal a fir cone. If a squirrel hears a mouse, it points at its direction. The caught out mouse than has to choose another squirrel. This game fosters auditory perception.

Furthermore, numerous options for games that may be played outdoors exist.

\subsection{Relaxation}

Psychomotor classes taking place in gyms often end with relaxations like imaginary journeys, progressive muscle relaxation or partner massages. Of course these may be transferred to natural settings, depending on weather conditions. Children might lay down on a meadow, close their eyes if they want to, perceive the underground they lay on as well as the wind in their hair and the sunrays on their skin and listen to surrounding sounds. The teacher might put a focus on perceiving different senses. Two more exemplified options are (Klein \& Kurth, 2017; Salz, 2003):

- "Identifying trees": Guided by a partner children feel the surface and shape of a tree with closed eyes. Afterwards, they step back, open their eyes and try to visually identify the tree they groped.

- "Earth window": Some children lay down on the ground on a comfortable place. The other children cover them with natural materials like branches, leaves, bark or moss. Eventually, only the head remains free. Thereby, children might feel like they are a part of earth.

The psychomotor session should always end with a ritualized goodbye completing the relaxation phase. This may be a short song or rhyme. 


\section{Conclusion}

Outdoor environments provide a great opportunity for children to participate in physical activity (Finn et al., 2018). The physical and mental health of children seems to benefit from contact with nature (Sharma-Brymer \& Bland, 2016). Thompson Coon et al. (2011) conducted a systematic review that revealed an association of exercising in natural environments with greater feelings of revitalization, positive engagement, decreases in tension, confusion, anger and depression and increased energy compared with exercising indoors.

Spending more time in nature leads to positive changes in behavior and the capacity to concentrate in children with attention-deficit disorder (Kuo \& Taylor, 2004). The risk of poor mental health is reduced by physical activity in natural environments to a greater extent than by physical activity in other environments. Compared to non-users, regular users of woods for physical activity were at about half the risk of poor mental health (Mitchell, 2013).

It is important to promote positive experiences of children in pleasant natural environments and to reconnect them with the natural world (Calogiuri, 2016). The concept of psychomotricity may be suitable for this purpose. Exemplified options of practical implementation have been shown above. These may be conducted in psychomotor sessions as well as in nature camps. Nature camp experiences in fifth-graders led to gains in areas of connection to, knowledge of, and orientation toward nature (San Jose \& Nelson, 2017). This is relevant regarding the fact that frequent experiences in nature during childhood predict higher levels of physical activity in natural environments in adulthood (Calogiuri, 2016). Bringing children back to nature may therefore lead to major public health effects. Projects like "ticket 2 nature" may provide appropriate starting points (Jacoby \& Kloth, 2008). Furthermore, the use of psychomotor approaches in natural surroundings has a great potential to include children with special needs (Klein, 2016), especially due to the above-mentioned principles of the child-centered approach.

Nevertheless, expected positive effects of outdoor psychomotor activities need to be verified in future empirical studies, for example regarding possible long-term effects concerning children's perception, motor skills and self-concept.

\section{References}

Calogiuri, G. (2016). Natural Environments and Childhood Experiences Promoting Physical Activity, Examining the Mediational Effects of Feelings about Nature and Social Networks. International Journal of Environmental Research and Public Health, 13, 1-21. https://doi.org/10.3390/ijerph13040439

Finn, K., Yan, Z., \& McInnis, K. (2018). Promoting Physical Activity and Science Learning in an Outdoor Education Program. Journal of Physical Education, Recreation \& Dance, 89, 35-39. https://doi.org/10.1080/07303084.2017.1390506

Grüger, C., \& Weyhe, S. (2007). Kinder in Bewegungmit NaturMotorik [Children in Motion with Nature Motor Activity.] Münster: Ökotopia.

Jacoby, T., \& Kloth, T. (2008). Feel Nature-Ticket to Nature. In A. Ferstl, M. Scholz, \& 
C. Thiesen (Eds.), Menschen stärken für globale Verantwortung [Empowering People for Global Responsibility] (pp. 153-162). Augsburg: Ziel.

Klein, D. (2016). Den Körper wahrnehmen-Psychomotorik im inklusiven Schulsport [Perceptionofthebody-Psychomotricity in Inclusive Physical Education]. In S. Ruin, S. Meier, H. Leineweber, D. Klein, \& C. Buhren (Eds.), Inklusion im Schulsport [Inclusion in Physical Education] (pp. 52-62). Weinheim: Beltz.

Klein, D., \& Kurth, A. (2017). Wahrnehmungsförderung durch Psychomotorik in der Natur [Promotion of Perception through Psychomotricity in Nature]. Motorik, 40, 56-62. https://doi.org/10.2378/Mot2017.art10d

Köckenberger, H. (2010). Psychomotorik [Psychomotricity]. In H. Lange, \& S. Sinning (Eds.), Handbuch Methoden im Sport [Handbook of Methods in Sports] (pp. 362-386). Balingen: Spitta.

Kruger, J., Nelson, K., Klein, P., McCurdy, L., Pride, P., \& Ady, J. (2010). Building on Partnerships: Reconnecting Kids with Nature for Health Benefits. Health Promotion Practice, 11, 340-346. https://doi.org/10.1177/1524839909348734

Kuo, F. E., \& Taylor, F. A. (2004). A Potential Natural Treatment for Attention-Deficit/Hyperactivity Disorder: Evidence from a National Study. American Journal of Public Health, 94, 1580-1586. https://doi.org/10.2105/AJPH.94.9.1580

Marshall, S., Biddle, S., Gorely, T., Cameron, N., \& Murdey, I. (2004). Relationships between Media Use, Body Fatness and Physical Activity in Children and Youth: A Meta-Analysis. International Journal of Obesity, 28, 1238-1246. https://doi.org/10.1038/sj.ijo.0802706

Mitchell, R. (2013). Is Physical Activity in Natural Environments Better for Mental Health Than Physical Activity in Other Environments? Social Science \& Medicine, 91, 130-134. https://doi.org/10.1016/j.socscimed.2012.04.012

Pesce, C., Masci, I., Marchetti, R., Vazou, S., Sääkslahti, A., \& Tomporowski, P. (2016). Deliberate Play and Preparation Jointly Benefit Motor and Cognitive Development: Mediated and Moderated Effects. Frontiers in Psychology, 7, 1-17. https://doi.org/10.3389/fpsyg.2016.00349

Roth, K., Ruf, K., Obinger, M., Mauer, S., Ahnert, J., Schneider, W., Graf, C., \& Hebestreit, H. (2010). Is There a Secular Decline in Motor Skills in Preschool Children? Scandinavian Journal of Medicine \& Science in Sports, 20, 670-678. https://doi.org/10.1111/j.1600-0838.2009.00982.x

Salz, B. (2003). Mein Freund, der Stein... Kindgemäße Entspannungmit Naturmaterialien [My friend, the Stone... Relaxation with Nature Material Suitable for Children]. Praxis der Psychomotorik, 28, 98-105.

San Jose, A. L., \& Nelson, K. E. (2017). Increasing Children's Positive Connection to, Orientation toward, and Knowledge of Nature through Nature Camp Experiences. International Journal of Environmental \& Science Education, 12, 933-944.

Sharma-Brymer, V., \& Bland, D. (2016). Bringing Nature to Schools to Promote Children's Physical Activity. Sports Medicine, 46, 955-962. https://doi.org/10.1007/s40279-016-0487-z

Strong, W., Malina, R., Blimkie, C., Daniels, S., Dishman, R., Gutin, B., Hergenroeder, A., Must, A., Nixon, P., Pivarnik, J., Rowland, T., Trost, S., \& Trudeau, F. (2005). Evidence Based Physical Activity for School-Age Youth. Journal of Pediatrics, 146, 732-737. https://doi.org/10.1016/j.jpeds.2005.01.055

Thompson Coon, J., Boddy, K., Stein, K., Whear, R., Barton, J., \& Depledge, M. (2011). Does Participating in Physical Activity in Outdoor Natural Environments Have a Greater Effect on Physical and Mental Wellbeing than Physical Activity Indoors? A 
Systematic Review. Environmental Science \& Technology, 45, 1761-1772.

https://doi.org/10.1021/es102947t

Tomkinson, G., Léger, L., Olds, T., \& Cazorla, G. (2003). Secular Trends in the Performance of Children and Adolescents (1980-2000). An Analysis of 55 Studies of the 20m Shuttle Run Test in 11 Countries. Sports Medicine, 33, 285-300.

https://doi.org/10.2165/00007256-200333040-00003

Wells, N. M., \& Lekies, K. S. (2006). Nature and the Life Course: Pathways from Childhood Nature Experiences to Adult Environmentalism. Children, Youth and Environments, 16, 1-24.

Zimmer, R. (2012). Handbook of Psychomotricity. Freiburg: Herder. 